\title{
Ocorrência de anticorpos para o vírus da língua azul em ovinos da região Centro-Sul do Paraná
}

Maria Carolina Ricciardi Sbizera, Luiz Fernando Coelho da Cunha Filho, José Victor Pronievicz Barreto, Daiene Locoman, Michele Monteiro Sudak, Manuela Venturelli Finco, Diego Fagner Michelasi de Souza

Universidade Norte do Paraná (UNOPAR), CIDADE, PR, Brasil

*Autor correspondente

e-mail: carolsbizera@hotmail.com

\section{Resumo}

A língua azul (LA) é uma doença viral, infecciosa e não contagiosa causada por um vírus (VLA) do gênero Orbivírus, transmitida por vetores hematófagos do gênero Culicoides aos ruminantes domésticos e selvagens, sobretudo nos ovinos, espécie mais suscetível. No Brasil, diversos estudos soroepidemiológicos, como a imunodifusão em gel de ágar (IDGA) e o ELISA-c, têm demonstrado a presença do vírus nas diferentes regiões do país. A ocorrência de anticorpos no país, muito provavelmente, está associada às condições climáticas, já que a maior parte do território brasileiro encontra-se em regiões de elevada temperatura e umidade, clima que propicia a multiplicação e a manutenção dos vetores. No Paraná, há relato de um surto da doença em 2001, porém, não existe um estudo epidemiológico da enfermidade em ovinos no estado. 0 Paraná possui condições climáticas de temperatura e umidade moderadas, nas diversas mesorregiões, ao longo de todo o ano, o que favorece a multiplicação do vetor, propiciando a ocorrência de ovinos soropositivos. 0 objetivo do trabalho foi avaliar a ocorrência de anticorpos para o vírus da língua azul na região noroeste do Paraná, Brasil. 0 experimento foi realizado na mesorregião Centro-Sul do Paraná, em três propriedades distintas, duas localizadas nos municípios de Candoi e uma no município de Pitanga. O clima nesta área é subtropical com verão temperado. Foram avaliadas 109 amostras de soro sanguíneo, provenientes de ovinos Texel, machos e fêmeas, de diversas idades, sem sinais clínicos da doença, submetidas ao kit de Imunodifusão em Gel de Ágar (IDGA) da VMRD ${ }^{\circledR}$, seguindo-se as recomendações do fabricante, para avaliação da sorologia para o VLA. As amostras que formaram linhas de precipitação foram consideradas positivas. 0 exame foi realizado no laboratório de microbiologia da UNOPAR, Campus Arapongas, PR. Os resultados revelaram que 31,19\% (34/109) dos ovinos testados na mesorregião Centro-Sul possuíram anticorpos para o VLA. Em Pitanga, a ocorrência foi de $44,74 \%$ de animais positivos, enquanto as duas propriedades de Candoi apresentaram $35,14 \%$ e $11,75 \%$ de soropositivos para língua azul. 0 clima da mesorregião pode ser uma 
justificativa à ocorrência, já que a temperatura média e a umidade elevada propiciam a multiplicação do vetor. Além disso, raças lanadas como os animais do estudo, são mais predisponentes. Ambas justificativas concordam com dados da literatura nacional. A ocorrência de anticorpos para o vírus da língua azul está presente em ovinos da região Centro-Sul do Paraná. 